\title{
Faktor-Faktor Non-Performing Financing (NPF) di Bank Umum Syariah Indonesia
}

\author{
Khofidlotur Rofi'ah dan Alvira 'Aina A'yun \\ Fakultas Ekonomi dan Bisnis, Universitas Airlangga Surabaya \\ Email: ${ }^{1}$ khofidlotur.rofiah-2018@pasca.unair.ac.id \\ ${ }^{2}$ alvira.aina.ayun-2018@pasca.unair.ac.id
}

\begin{abstract}
The bank's task is as an intermediary institution that is funding and lending. OJK Data shows that each year financing in Sharia banks continues to increase. Therefore sharia banking should prevent the minimum financing to occur and be obliged to know what the factors of the NPF are in order to maintain banking health. The purpose of this research is to know the NPF factors in Indonesia's Sharia bank. The research method used in this research is to use quantitative research with a double linear regression approach. The data used in this study was a monthly data series from the year 2014-2018. The variables used in this study are NPF as variable dependent and CAR, FDR, inflation, SBIS, BOPO as independent variables. The result in the study was the CAR and FDR impactful negative and significant to the NPF, inflation and SBIS impact negative and insignificant, while BOPO influential positive and significant.
\end{abstract}

Keywords: Non-Performing Financing, CAR, FDR, Inflation, SBIS.

\section{PENDAHULUAN}

Bank ialah Suatu badan usaha yang melakukan tugas penghimpunan Dana dan penyaluran Dana kepada masyarakat dengan tujuan untuk membantu dalam peningkatan perekonomian masyarakat. Adapun yang dimaksud bank syariah adalah sebagai lembaga intermediasi yang Sama halnya beroperasi sesuai yang dilakukan oleh bank konvensional, yaitu menerima tabungan atau Dana dari masyarakat dan juga memberikan pembiayaan kepada masyarakat yang membutuhkan. Namun transaksi dilakukan sesuai dengan prinsip-prinsip Islam, atau tidak bertentangan dengan ajaran Islam. Tercatat dalam laporan Bank Indonesia yaitu ada 22 UUS, 163 BPRS, dan 20 BUS (Www.bi.go.id, n.d.) Berkembangnya jumlah perbankan syariah di Indonesia tersebut sejalan dengan perkembangan kinerja perbankan syariah yang kinerjanya dapat dikatakan baik tiap tahunnya, serta banyaknya pembiayaan yang disalurkan. Meningkatnya pembiayaan dalam perbankan syariah ditandai dengan banyaknya nasabah yang melakukan pembiayaan, hal ini ditunjukkan oleh laporan dari data Otoritas Jasa Keuangan (OJK) bahwa total pembiayaan di tahun 2014-2018, sebagai berikut: (www.ojk.go.id, n.d.) 
Gambar 1. Total pembiayaan

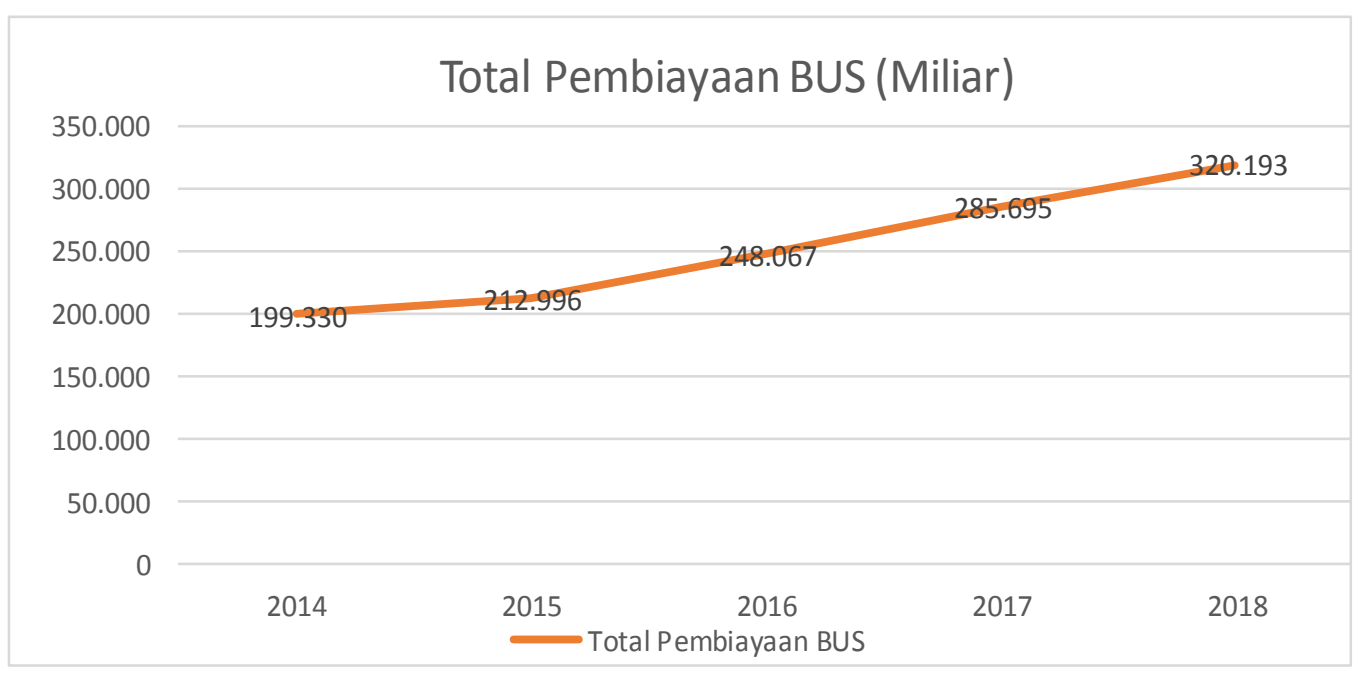

Sumber: OJK

Gambar 1. Tersebut adalah total data pembiayaan berdasarkan akad-akad yang ada di perbankan syariah. Dari Gambar tersebut menunjukkan bahwa pembiayaan di perbankan syariah tiap tahunnya mengalami peningkatan. Oleh karena itu perbankan mempunyai tanggung jawab terhadap penyaluran Dana agar dapat mengurangi resiko pembiayaan macet.

Resiko pembiayaan merupakan suatu hal yang harus diperhatikan dan di analisis penyebabnya yang dapat menyebabkan perbankan dalam keadaan yang buruk. Hal ini juga dapat disebabkan oleh tingginya pengeluaran nilai yang dapat menyebabkan perbankan tersebut mengalami penurunan modal bank. Yang dapat menyebabkan kerugian dalam perbankan akibat resiko yang di dapat adalah besarnya pembiayaan kredit yang macet atau non-performing financing. NPF yaitu rasio antara pembiayaan kredit macet dengan total keseluruhan pembiayaan yang diberikan kepada nasabah (Asnaini, 2014). Jika NPF dalam suatu perbankan semakin tinggi, maka tingkat resiko yang di dapat Akan lebih tinggi juga. Oleh karena itu pihak bank wajib untuk menyediakan Dana cadangan guna untuk mengurangi modal Dana bank (Rafsanjani, 2018)

Tidak dapat dipungkiri bahwa NPF Akan selalu menjadi resiko bagi pihak bank. Tetapi resiko tersebut dapat dikurangi dengan adanya kebijakan untuk Dana pembiayaan yang digunakan untuk membiayai nasabah, namun dengan Cara hati-hati. Misalnya menganalisis data nasabah dengan baik. Selain itu bank juga dapat melakukan dengan Cara melatih pegawai-pegawai yang dikhususkan untuk menangani dalam pembiayaan. Tidak lain hal ini diperuntukkan untuk meminimalisasi pembiayaan kredit macet. (Rafsanjani, 2018)

Selain itu, faktor-faktor NPF juga suatu hal yang penting yang harus diketahui oleh perbankan, dengan tujuan digunakan untuk referensi bagi perbankan dalam mengelola resiko pembiayaan yang dihadapi. Berdasarkan dari paparan latar belakang, maka penelitian selanjutnya ialah untuk mengetahui determinant yang dapat mempengaruhi nonperforming financing dengan menggunakan variabel CAR, FDR, Inflasi, SBIS dan BOPO sebagai penentu faktor yang menyebabkan terjadinya pembiayaan macet. Dengan 
dilakukannya penelitian ini maka hasil Akan penting bagi pihak perbankan, Bank Indonesia dan juga Pemerintah dalam membuat kebijakan yang tepat untuk keberlanjutan pengembangan perbankan syariah di Indonesia.

\section{KAJIAN TEORI}

Non-Performing Financing (NPF). Ialah kegiatan pembiayaan merupakan salah satu operasional perbankan yaitu dalam bidang untuk membantu pemenuhan Dana bagi pihakpihak yang membutuhkan Dana untuk kegiatan usaha maupun konsumsi. Pihak bank berkomitmen untuk memberikan pelayanan yang terbaik bagi nasabah dalam segi fasilitas atau yang lainnya. Oleh karena itu pihak bank berkewajiban untuk merealisasikan komitmen tersebut agar tidak berdampak buruk bagi profitabilitas bank. Selain itu bank juga Akan kemungkinan untuk menghadapi tuntutan dalam ganti rugi (Zainul, 2006)

Penelitian yang dilakukan oleh (Umar dan Sun, 2016) terkait faktor atau penentu pembiayaan bermasalah (Non-Performing Loan), khusus penelitian dilakukan di Bank China. Variabel independen yang digunakan adalah pertumbuhan PDB, tingkat bunga, inflasi dan nilai tukar mata uang asing. Hasil menunjukkan bahwa semua dari variabel independen tersebut signifikan terhadap NPL di bank china. Penelitian ini fokus pada bank konvensional, sedangkan dalam penelitian ini fokus pada bank syariah. Penelitian yang dilakukan (Ghosh, 2017) fokus untuk mengkaji dampak dari NPL pada aspek kegiatan ekonomi riil di AS. Menggunakan data semua perbankan yang ada di AS dari tahun 19842016. Temuan dari penelitian ini yaitu dampak dari NPL ketika mengalami kenaikan, maka berpengaruh pada pertumbuhan PDB riil di AS, demikian juga NPL menurun, maka secara signifikan berdampak juga pada penurunan pertumbuhan lapangan kerja, aktivitas keuangan lainnya dikarenakan penurunan pinjaman oleh konsumen. Sehingga uji penelitian ini menunjukkan dampak yang negatif NPL terhadap pertumbuhan GDP.

Sehingga dalam penelitian selanjutnya adalah mencoba untuk mengetahui faktorfaktor pembiayaan bermasalah (NPF) yang hanya fokus pada bank syariah di Indonesia saja. Serta menguji data dari tahun 2014-2018. Menggunakan variabel independen CAR, FDR, Inflasi, SBIS dan BOPO.

Menurut (Husaeni, 2016) bahwa sebab terjadinya pembiayaan kredit macet yaitu dapat disebabkan oleh beberapa faktor yaitu;

Faktor Internal. Faktor eksternal yaitu meliputi manajerial di perusahaan perbankan yang meliputi baik buruknya kebijakan dalam pembelian dan penjualan, pengawasan biaya pengeluaran yang kurang tepat, kurangnya ketepatan dalam kebijakan piutang, berlebihanya dalam penempatan aktiva dan pemodalan yang kurang cukup. Rasio keuangan yang sering digunakan untuk menilai kondisi internal perusahaan yaitu; Dana Pihak Ketiga (DPK), Capital Adequacy Rasio (CAR), Financing Deposit Rasio (FDR), Non Performing Financing (NPF) dan Return On Aset (ROA)

Faktor Eksternal. Faktor eksternal yaitu meliputi manajerial di luar perusahaan, seperti misalnya terjadinya bencana alam, berkembangnya teknologi.

Inflasi. Beberapa literature menjelaskan bahwa inflasi didefinisikan sebagai kenaikan harga umum secara terus menerus dari suatu perekonomian. Pengaruh inflasi terhadap 
NPF yaitu jika inflasi tinggi maka pendapatan riil masyarakat Akan menurun begitu juga dengan konsumsi masyarakat yang Akan menurun. Dan ketika terjadi inflasi maka hargaharga barang Akan mengalami kenaikan yang cukup tinggi dari harga sebelumnya, sehingga seorang debitur Akan sulit untuk membayar angsuran pembiayaan pada perbankan setiap bulannya, karena pendapatan yang dihasilkan oleh debitur habis digunakan untuk memenuhi kebutuhannya dalam sehari-hari (Setyawati et al., 2017)

Penelitian yang berjudul "Determinants of non-performing loans in small developing economies: a case of Fiji's banking sector" (Kumar, 2015). Fokus penelitian ini yaitu peneliti ingin mengetahui faktor-faktor penentu NPL khususnya pada ekonomi makro, seperti pertumbuhan ekonomi, inflasi, dan pengangguran di perbankan Fiji, data diambil dari tahun 2000-2013 yang di dapat dari 5 bank komersial dan 2 lembaga keuangan nonbank. Hasil penelitian menunjukkan ada beberapa indikator yang mempunyai hubungan negative dengan NPL dan secara signifikan indikator tersebut karena adanya persyaratan kecukupan modal, pangsa pasar berdasarkan asset dan pengangguran. Di sisi lain interest margin mempunyai hubungan yang positif terhadap NPL.

Penelitian dengan judul "Determinants of Non Performing Financing in Indonesian Islamic Banks" (Sukmana, 2015), fokus meneliti pada faktor-faktor penentu pembiayaan di perbankan syariah dan perbankan konvensional. Data diambil dari tahun 2004-2014 dengan variabel kecukupan modal, tingkat pembiayaan, tingkat suku bunga, pembiayaan syariah, pinjaman konvensional, indeks produksi industri sebagai proxy untuk PDB, harga, dan nilai tukar. Hasil dari penelitian tersebut menunjukkan bahwa NPF perbankan syariah lebih efektif dalam mengembangkan sektor riil dari pada perbankan konvensional, untuk itu NPF harus diterapkan di perbankan konvensional.

"Non-performing loans and financial development: new evidence" (Ozili, 2017) penelitian ini berfokus meneliti tentang faktor-faktor penentu NPL dan pengaruh pengembangan keuangan terhadap NPL khususnya di bank sentral Nigeria, data diambil dari tahun 2003-2014. Hasil menunjukkan bahwa pengembangan keuangan mempunyai pengaruh yang positif terhadap NPL, sebaliknya krisis keuangan atau inflasi juga pengaruh negatif terhadap NPL.

Penelitian selanjutnya yaitu "The impact of control quality on the non-performing loans of Tunisian listed banks" (Ben Saada, 2018). Penelitian ini bertujuan untuk mengeksplorasi sejauh mana perbankan tersebut melakukan kontrol terhadap dampak NPL yang mengintegrasikan pedoman No. Edaran 2011-06 yang dikeluarkan pada 20 Mei 2011 oleh bank sentral Tunisia. Data diperoleh dari 11 perbankan yang terdaftar secara resmi di Tunisia selama periode 2010-2015. Hasil penelitian ini menunjukkan bahwa dengan adanya pengawasan terhadap pembiayaan kredit bermasalah lebih efektif dibanding dengan tidak menerapkan nya karena dengan adanya pengawasan direksi yang berfokus pada NPL maka dapat mengurangi pembiayaan kredit bermasalah.

Financing to Deposit Ratio (FDR). Pengukuran likuiditas dalam perbankan dapat diukur dengan menggunakan berbagai pengukuran, salah satunya adalah Loan to Deposit Ratio ialah kemampuan bank dalam membayar kembali penarikan Dana yang dilakukan oleh nasabah dengan mengandalkan dana yang diberikan sebagai sumber likuiditas nya (Vanni dan Rokhman, 2018)

FDR adalah rasio antara pembiayaan yang diberikan oleh bank dari Dana pihak ketiga yang dikumpulkan oleh bank. Rasio FDR adalah rasio yang digunakan untuk 
mengukur tingkat likuiditas bank, yang dapat menunjukkan bahwa bank mampu memenuhi permintaan kredit dengan menggunakan total asset bank. Nilai FDR yang diperbolehkan oleh Bank Indonesia adalah kisaran 78\%-100\% (Husaeni, 2016)

Tingginya FDR menyebabkan dampak yang baik dalam menggerakkan perekonomian. Karena salah satu indicator lajunya perekonomian nasional adalah dari perbankan. Ketika FDR maka pembiayaan di perbankan juga Akan meningkat (Wibowo, 2015). Rasio ini disebut juga dengan rasio kredit. Penyaluran pembiayaan merupakan kegiatan utama bank. Semakin tinggi pembiayaan yang dikeluarkan oleh pihak Dana, artinya semakin tinggi juga terhadap resiko yang Akan dihadapi. Dengan menggunakan ukuran ratio FDR ini yaitu untuk mengetahui baik atau buruknya kemampuan bank dalam menjalankan kegiatan usaha. Dengan kesimpulan bahwa FDR yaitu digunakan sebagai indikator dalam mengetahui tingkat kerawanan bank.

Capital Adequacy Ratio (CAR). Capital Adequacy Ratio (CAR) adalah rasio kecukupan modal yang mempunyai fungsi untuk menanggung kerugian yang dihadapi oleh bank. Semakin tinggi CAR dalam perbankan maka Akan semakin baik pula kemampuan bank tersebut dalam mengelola resiko. Berdasarkan definisi tersebut maka ketika nilai CAR tinggi hal tersebut Akan berdampak baik pada perbankan, yaitu dapat memberikan kontribusi yang cukup besar bagi profitabilitas bank. Dengan adanya CAR sebagai salah satu indikator kemampuan bank dalam menanggung resiko yang dihadapi, maka tingkat kecukupan modal dalam pembiayaan Akan lebih mudah untuk menurunkan nilai NPF.

SBIS. SBIS merupakan Surat berharga yang diterbitkan oleh Bank Indonesia dengan berdasarkan aturan Islam yang berjangka waktu pendek dengan mata uang rupiah. Fungsi lain dari SBIS yaitu untuk pengendalian moneter yang diterbitkan sebagai salah satu instrument Operasi Pasar Terbuka (OPT) dengan menggunakan akad-akad yang tidak bertentangan dengan Islam, yaitu SBIS dilakukan dengan akad jualah. Karena SBIS merupakan sarana investasi bagi perbankan yang diharapkan untuk memperoleh keuntungan atau return. Sehingga dengan memperoleh return bank dapat mengeluarkan pembiayaan yang lebih tinggi kepada masyarakat (Dahlan, 2015)

Dengan berjalannya SBIS maka perbankan Akan mengalami penurunan pembiayaan, karena Dana yang seharusnya digunakan untuk pembiayaan diinvestasikan. Maka dalam hal ini perbankan juga diuntungkan karena menurunnya resiko bermasalah.

Penelitian yang dilakukan oleh (Beck dan Jakubik, 2013) bahwa analisisnya tentang exchange rate secara empiris menunjukkan bahwa pertumbuhan NPL secara sistematis terkait dengan penurunan harga saham memperoleh hasil yang signifikan.

BOPO. BOPO merupakan rasio untuk mengukur efisiensi perbankan dalam penggunaan biaya ketika melakukan kegiatan operasionalnya, bank sebagai agent of trust, agent of development, dan agent of services. Maka tugas bank yaitu menjalankan kegiatan menyalurkan Dana dan menghimpun Dana kepada masyarakat.

Biaya operasional merupakan biaya yang dikeluarkan oleh bank dalam menjalankan aktivitas usaha pokok, seperti biaya bunga, biaya tenaga kerja, biaya pemasaran, dan biaya operasi lainnya. Pendapatan operasional merupakan pendapatan utama bagi bank yaitu yang diperoleh dari salah satunya pembiayaan kredit. Semakin kecil rasio BOPO artinya 
semakin efisien biaya operasional yang dikeluarkan bank. Sehingga pembiayaan bermasalah di bank semakin rendah.

Hasil analisis oleh (Wahyuni dan Wiagustini, 2016) yang fokus penelitian pada objek Bursa Efek Indonesia, dengan hasil bahwa BOPO mempunyai pengaruh yang negatif signifikan terhadap profitabilitas perusahaan. Penelitian ini memperoleh data dengan menggunakan purposive sampling, sampel yang digunakan adalah perusahaanperusahaan yang terdaftar di Bursa Efek Indonesia pada tahun 2011-2013.

\section{METODOLOGI}

Data. Data yang digunakan dalam penelitian ini adalah berupa data time series bulanan yaitu dari tahun 2014 hingga 2018. Yang dimaksud data time series ialah data yang dikeluarkan oleh Bank Indonesia dalam urutan waktu, yaitu berupa data mingguan, bulanan, dan tahunan. Selanjutnya sumber data yang di dapat dari penelitian ini yaitu data dari laporan Otoritas Jasa Keuangan dan data dari laporan Bank Indonesia. Adapun variabel yang digunakan dalam penelitian ini yaitu NPF, dimana NPF sebagai variabel dependen, sedangkan variabel independen nya yaitu CAR, FDR, Inflasi, SBIS dan BOPO.

Tabel 1. Ringkasan Definisi Operasional Variable

\begin{tabular}{|c|c|c|c|c|c|c|}
\hline No & Variable & Definisi & $\begin{array}{c}\text { Sumber } \\
\text { data }\end{array}$ & $\begin{array}{c}\text { Skala } \\
\text { pengukur }\end{array}$ & $\begin{array}{l}\text { Jenis } \\
\text { data }\end{array}$ & Periode \\
\hline 1 & NPF & $\begin{array}{l}\text { Non Performing } \\
\text { Financing (pembiayaan } \\
\text { kredit macet) }\end{array}$ & OJK & Persentase & $\begin{array}{l}\text { Time } \\
\text { series }\end{array}$ & $\begin{array}{c}2014- \\
2018\end{array}$ \\
\hline 2 & CAR & $\begin{array}{l}\text { Capital Adequacy Ratio } \\
\text { (Rasio pemodalan) bank } \\
\text { syariah }\end{array}$ & OJK & Persentase & $\begin{array}{l}\text { Time } \\
\text { series }\end{array}$ & $\begin{array}{l}2014- \\
2018\end{array}$ \\
\hline 3 & FDR & $\begin{array}{l}\text { Financing to Deposit } \\
\text { Ratio (pembiayaan dana } \\
\text { kepada pihak ke tiga) } \\
\text { bank syariah }\end{array}$ & OJK & Persentase & $\begin{array}{l}\text { Time } \\
\text { series }\end{array}$ & $\begin{array}{l}2014- \\
2018\end{array}$ \\
\hline 4 & Inflasi & Meningkatnya harga & BI & Persentase & $\begin{array}{l}\text { Time } \\
\text { series }\end{array}$ & $\begin{array}{l}2014- \\
2018\end{array}$ \\
\hline 5 & SBIS & $\begin{array}{l}\text { Sertifikat bank Indonesia } \\
\text { syariah }\end{array}$ & OJK & Rupiah & $\begin{array}{l}\text { Time } \\
\text { series }\end{array}$ & $\begin{array}{l}2014- \\
2018\end{array}$ \\
\hline 6 & BOPO & $\begin{array}{l}\text { Biaya Operasional } \\
\text { Pendapatan Operasional }\end{array}$ & OJK & Persentase & $\begin{array}{l}\text { Time } \\
\text { series }\end{array}$ & $\begin{array}{l}2014- \\
2018\end{array}$ \\
\hline
\end{tabular}

Sumber: (Data diolah, 2019)

Regresi Linier Berganda. Penelitian ini menggunakan metode kuantitatif dengan pendekatan regresi linier berganda yang diolah dengan aplikasi e-views 9. Data yang digunakan adalah data sekunder dari data laporan statistik Perbankan Syariah dari Otoritas Jasa Keuangan (OJK) dan Bank Indonesia (BI) untuk memperoleh data dari Bank Umum Syariah di Indonesia, yaitu mulai dari tahun 2014-2018. Analisis regresi linier berganda ini digunakan untuk menguji pengaruh variabel-variabel independen terhadap variabel 
dependen. Adapun model regresi linier berganda dapat diketahui sebagai berikut: (Nur dan Lintang, 2018).

$$
Y=a+b_{1} X_{1}+b_{2} X_{2}+b_{3} X_{3}+b_{4} X_{4}+b_{5} X_{5}+e
$$

$$
\begin{aligned}
& \text { Dimana: } \\
& Y=\text { NPF } \\
& a=\text { Konstanta } \\
& \mathrm{b}_{1} \mathrm{~b}_{2} \mathrm{~b}_{3} \mathrm{~b}_{3} \mathrm{~b}_{4} \mathrm{~b}_{5}=\text { Koefisien regresi } \\
& \mathrm{X}_{1}=\text { CAR } \\
& \mathrm{X}_{2}=\text { FDR } \\
& \mathrm{X}_{3}=\text { Inflasi } \\
& \mathrm{X}_{4}=\text { SBIS } \\
& \mathrm{X}_{5}=\text { BOPO }
\end{aligned}
$$

Sebelum menguji regresi linier berganda, diperlukan uji asumsi klasik terlebih dahulu, tes yang dilakukan adalah uji normalitas, multikoloniaritas, heterokedastisitas, dan autokorelasi. Dengan demikian model yang digunakandalam hipotesis penelitian ini adalah sebagai berikut:

Gambar 2. Model Penelitian

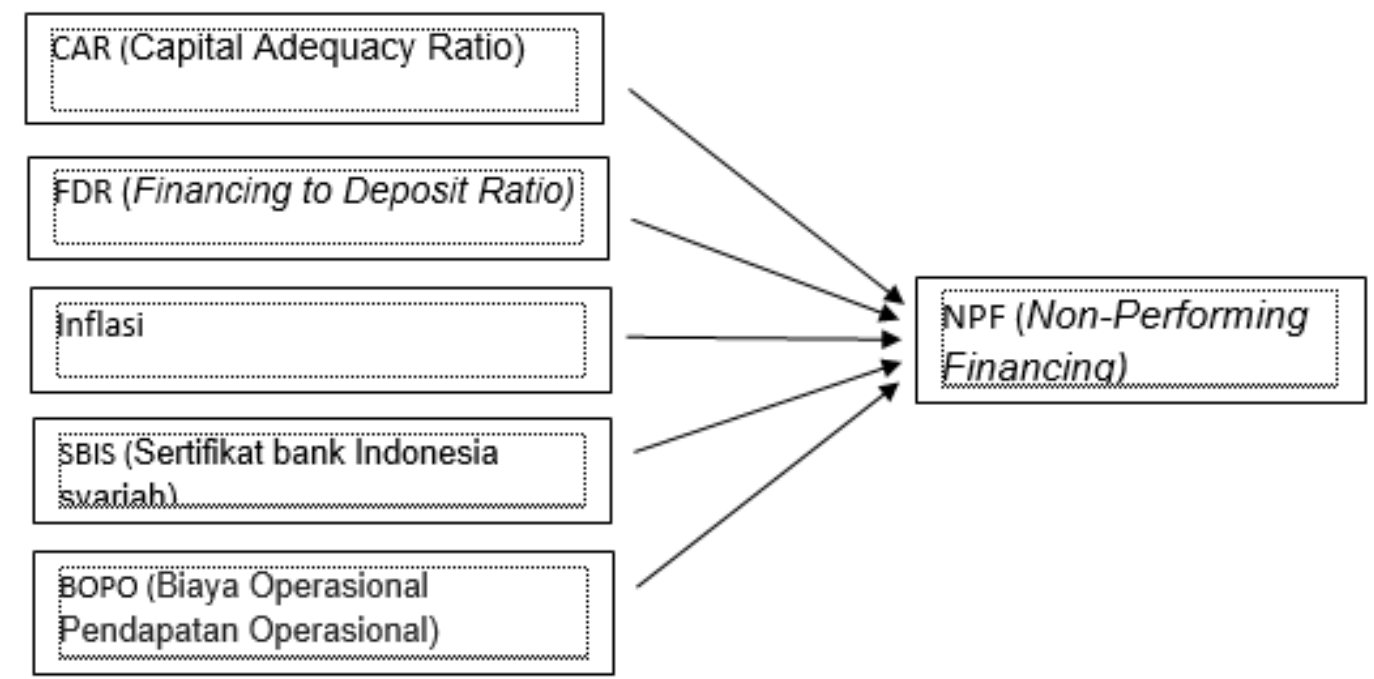

Sumber: (Penulis, 2019)

\section{HASIL DAN PEMBAHASAN}

Pada bagian ini membahas hasil tes dan diikuti oleh analisis, study ini telah dilakukan uji asumsi klasik normalitas, heteroskedasitas, multikolinearitas dan autokorelasi. Ukuran signifikansi dalam penelitian ini adalah 0,05 dan 0,01 atau 0,5\% dan 1,0\% Selain itu, urutan diskusi akan mulai dari CAR, FDR, Inflasi, SBIS, BOPO. 
Gambar 3. Hasil Uji Normalitas

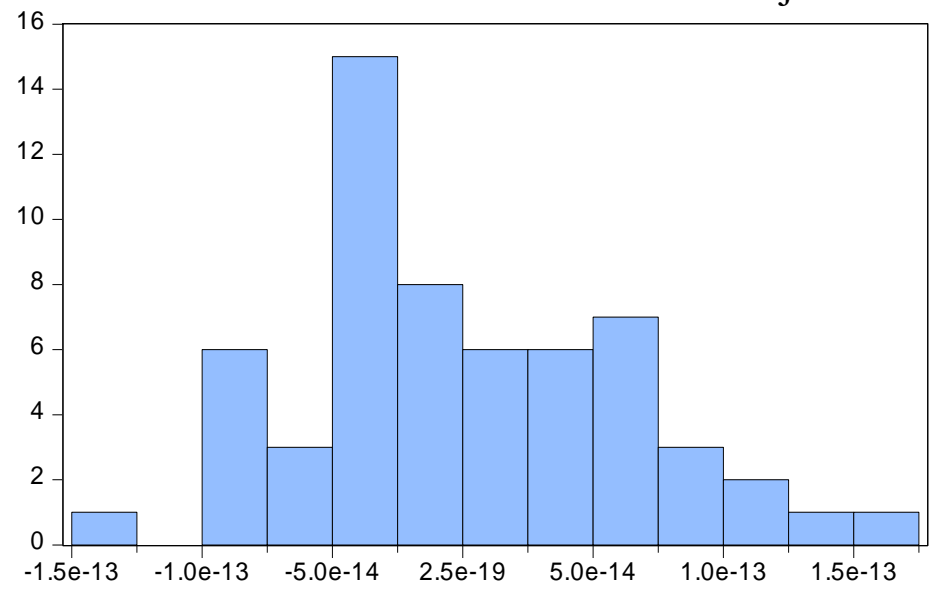

\begin{tabular}{|lc|}
\hline \multicolumn{2}{|l|}{ Series: Residuals } \\
Sample 2014M01 2018M11 \\
Observations 59 \\
Mean & $9.05 \mathrm{e}-16$ \\
Median & $-1.64 \mathrm{e}-14$ \\
Maximum & $1.54 \mathrm{e}-13$ \\
Minimum & $-1.49 \mathrm{e}-13$ \\
Std. Dev. & $6.21 \mathrm{e}-14$ \\
Skewness & 0.294350 \\
Kurtosis & 2.766131 \\
& \\
Jarque-Bera & 0.986435 \\
Probability & 0.610658 \\
\hline
\end{tabular}

Uji normalitas bertujuan untuk menguji apakah dalam uji regresi variabel pengganggu memiliki distribusi normal atau tidak. Berdasarkan gambar 3 menunjukkan bahwa nilai probabilitas 0.610 yang berarti apabila nilai probabilitas signifikansi lebih dari 0, 05 maka data penelitian ini ber distribusi secara normal.

Tabel 2. Uji Multikolinieritas

\begin{tabular}{|c|c|c|c|c|c|c|}
\hline & NPF & CAR & FDR & INFLASI & SBIS & ВOPO \\
\hline NPF & 1 & $\begin{array}{c}- \\
0.635907485 \\
2221766\end{array}$ & $\begin{array}{c}- \\
0.0450527523 \\
3909898\end{array}$ & $\begin{array}{c}- \\
0.01023338610 \\
616651\end{array}$ & $\begin{array}{c}- \\
0.00211767628949 \\
762\end{array}$ & $\begin{array}{c}0.60982257033397 \\
8\end{array}$ \\
\hline CAR & $\begin{array}{c}- \\
0.635907485 \\
2221766\end{array}$ & 1 & $\begin{array}{c}0.5878596181 \\
192154\end{array}$ & $\begin{array}{c}- \\
0.46089711420 \\
91315\end{array}$ & $\begin{array}{c}0.44671281966365 \\
6\end{array}$ & $\begin{array}{c}- \\
0.28286947730896 \\
26\end{array}$ \\
\hline FDR & $\begin{array}{c}- \\
0.045052752 \\
33909898\end{array}$ & $\begin{array}{c}- \\
0.587859618 \\
1192154\end{array}$ & 1 & $\begin{array}{c}0.67431799129 \\
66998\end{array}$ & $\begin{array}{c}- \\
0.81058846052470 \\
78\end{array}$ & $\begin{array}{c}- \\
0.40102558990893 \\
46\end{array}$ \\
\hline INFLASI & $\begin{array}{c}- \\
0.010233386 \\
10616651\end{array}$ & $\begin{array}{c}- \\
0.460897114 \\
2091315\end{array}$ & $\begin{array}{c}0.6743179912 \\
966998\end{array}$ & 1 & $\begin{array}{c}- \\
0.52117030708099 \\
46\end{array}$ & $\begin{array}{c}- \\
0.19513137423569 \\
84\end{array}$ \\
\hline SBIS & $\begin{array}{c}- \\
0.002117676 \\
28949762\end{array}$ & $\begin{array}{c}0.446712819 \\
663656\end{array}$ & $\begin{array}{c}- \\
0.8105884605 \\
247078\end{array}$ & $\begin{array}{c}- \\
0.52117030708 \\
09946\end{array}$ & 1 & $\begin{array}{c}0.23651332478151 \\
58\end{array}$ \\
\hline BOPO & $\begin{array}{c}0.609822570 \\
333978\end{array}$ & $\begin{array}{c}- \\
0.282869477 \\
3089626\end{array}$ & $\begin{array}{c}- \\
0.4010255899 \\
089346\end{array}$ & $\begin{array}{c}- \\
0.19513137423 \\
56984\end{array}$ & $\begin{array}{c}0.23651332478151 \\
58\end{array}$ & 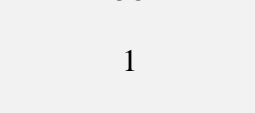 \\
\hline
\end{tabular}

Model analisis regresi yang baik adalah tidak terjadi korelasi antar variabel dependen dan variabel independen. Selanjutnya yaitu dilakukan Uji multikoloniaritas untuk mengetahui apakah terjadi korelasi antar variabel independen dan variabel dependen. Untuk dikatakan hasil uji multikoloniaritas yang baik adalah dengan melihat hasil uji nilai tolerance dan nilai Variance Inflation Factor. Jika nilai tolerance lebih besar dari 0, 10 maka tidak ada korelasi antar variabel dependen dengan variabel independen dan jika nilai Variance Inflation Factor lebih besar dari 0, 10 maka hasil uji tersebut terkena multikolonieritas. Pada tabel 2 menunjukkan bahwa hasil dari uji 
Multikolonieritas lebih dari 0, 10. Dengan demikian maka variabel dalam penelitian ini bebas dari multikolonieritas.

Tabel 3. Uji Heterokedastisitas

\begin{tabular}{llll} 
Heteroskedasticity Test: Breusch-Pagan-Godfrey & \\
\hline \hline F-statistic & 2.664971 & Prob. F(6,52) & 0.0249 \\
Obs*R-squared & 13.87560 & Prob. Chi-Square(6) & 0.0311 \\
Scaled explained SS & 9.611830 & Prob. Chi-Square(6) & 0.1420 \\
\hline \hline
\end{tabular}

Test Equation:

Dependent Variable: RESID^2

Method: Least Squares

Date: 09/23/19 Time: 10:49

Sample: 2014M01 2018M11

Included observations: 59

\begin{tabular}{crcrr}
\hline \hline Variable & Coefficient & Std. Error & t-Statistic & Prob. \\
\hline \hline C & $1.10 \mathrm{E}-25$ & $4.94 \mathrm{E}-26$ & 2.228366 & 0.0302 \\
NPF & $-5.21 \mathrm{E}-27$ & $1.70 \mathrm{E}-27$ & -3.060781 & 0.0035 \\
CAR & $-1.70 \mathrm{E}-27$ & $7.69 \mathrm{E}-28$ & -2.212901 & 0.0313 \\
FDR & $-4.98 \mathrm{E}-28$ & $2.68 \mathrm{E}-28$ & -1.857812 & 0.0689 \\
INFLASI & $8.87 \mathrm{E}-28$ & $5.20 \mathrm{E}-28$ & 1.706596 & 0.0939 \\
SBIS & $-3.01 \mathrm{E}-31$ & $4.95 \mathrm{E}-31$ & -0.608654 & 0.5454 \\
BOPO & $-1.26 \mathrm{E}-28$ & $1.64 \mathrm{E}-28$ & -0.763981 & 0.4483 \\
\hline R-squared & 0.235180 & Mean dependent var & $3.79 \mathrm{E}-27$ \\
Adjusted R-squared & 0.146931 & S.D. dependent var & & $1.16 \mathrm{E}-27$ \\
S.E. of regression & $4.72 \mathrm{E}-27$ & Sum squared resid & & 1.921479 \\
F-statistic & 2.664971 & Durbin-Watson stat & \\
Prob(F-statistic) & 0.024903 & & \\
\hline \hline
\end{tabular}

Dalam uji statistik ini, untuk mendeteksi adanya atau tidaknya heterokedastisitas dilakukan dengan uji white dengan melihat nilai probability Chi-square, jika nilai probability chi-square lebih besar dari tingkat signifikan 0,05 atau 5\% maka variabel dalam penelitian ini tidak terkena heterokedastisitas. Sebaliknya jika nilai nilai probabilitas Chi-square lebih kecil dari tingkat signifikan 0,05 maka variabel pada penelitian ini terkena heterokedastisitas. Berdasarkan tabel 3 dapat diketahui bahwa 0,142 $>0,05$ yang berarti bahwa dalam uji ini tidak terkena heterokedastisitas. 
Tabel 4. Uji Autokorelasi

Breusch-Godfrey Serial Correlation LM Test:

\begin{tabular}{llr}
\hline \hline 1.833966 & Prob. F(2,15) & 0.1938 \\
4.519110 & Prob. Chi-Square(2) & 0.1044 \\
\hline \hline
\end{tabular}

Berdasarkan tabel 4 dapat diketahui bahwa nilai probability Chi-aquare 0,104. Nilai ini lebih besar dari tingkat signifikan 0, 05 maka dapat disimpulkan bahwa uji ini tidak terdapat masalah autokorelasi.

Tabel 5. Hasil Pengujian Hipotesis

\begin{tabular}{|c|c|c|c|c|}
\hline \multicolumn{5}{|c|}{$\begin{array}{l}\text { Dependent Variable: NPF } \\
\text { Method: Least Squares } \\
\text { Date: 09/23/19 Time: 11:01 } \\
\text { Sample (adjusted): 2014M01 2018M11 } \\
\text { Included observations: } 59 \text { after adjustments }\end{array}$} \\
\hline Variable & Coefficient & Std. Error & t-Statistic & Prob. \\
\hline $\mathrm{C}$ & 14.27432 & 3.471969 & 4.111305 & 0.0001 \\
\hline CAR & -0.309793 & 0.045090 & -6.870501 & 0.0000 \\
\hline FDR & -0.057782 & 0.020110 & -2.873356 & 0.0058 \\
\hline INFLASI & -0.033168 & 0.041663 & -0.796099 & 0.4295 \\
\hline SBIS & $-4.54 \mathrm{E}-05$ & $3.94 \mathrm{E}-05$ & -1.151126 & 0.2548 \\
\hline BOPO & 0.012937 & 0.013139 & 0.984584 & 0.3293 \\
\hline R-squared & 0.694993 & \multicolumn{2}{|c|}{ Mean dependent var } & 4.745254 \\
\hline $\begin{array}{l}\text { Adjusted R- } \\
\text { squared }\end{array}$ & 0.666219 & \multicolumn{2}{|c|}{ S.D. dependent var } & 0.658565 \\
\hline $\begin{array}{l}\text { S.E. of } \\
\text { regression }\end{array}$ & 0.380478 & \multicolumn{2}{|c|}{ Akaike info criterion } & 1.001368 \\
\hline $\begin{array}{l}\text { Sum squared } \\
\text { resid } \\
\text { Log }\end{array}$ & 7.672471 & \multicolumn{2}{|l|}{ Schwarz criterion } & 1.212643 \\
\hline likelihood & -23.54036 & \multicolumn{2}{|c|}{ Hannan-Quinn criter. } & 1.083841 \\
\hline F-statistic & 24.15331 & \multicolumn{2}{|c|}{ Durbin-Watson stat } & 1.068813 \\
\hline $\begin{array}{l}\text { Prob(F- } \\
\text { statistic) }\end{array}$ & 0.000000 & & & \\
\hline
\end{tabular}

Sumber: (Data diolah, 2019)

Dari tabel 5 menunjukkan dua variabel berada pada tingkat singnifikan 0,05 yaitu variabel CAR dan FDR. Sedangkan variabel Inflasi, SBIS memiliki pengaruh yang negative terhadap dan BOPO berpengaruh positif. 
Tabel 6. Hasil Uji Kelayakan Model

$\begin{array}{llll}\begin{array}{l}\text { R-squared } \\ \text { Adjusted R- } \\ \text { squared }\end{array} & 0.694993 & \text { Mean dependent var } & 4.745254 \\ \begin{array}{l}\text { Sum squared } \\ \text { resid }\end{array} & 0.666219 & \text { S.D. dependent var } & 0.658565 \\ \begin{array}{l}\text { F-statistic } \\ \text { Prob(F- }\end{array} & 7.672471 & \text { Schwarz criterion } & 1.212643 \\ \text { statistic) } & 24.15331 & \text { Durbin-Watson stat } & 1.068813 \\ & 0.000000 & & \end{array}$

Sumber: (data diolah, 2019)

Dari tabel 6 didapatkan hasil uji $\mathrm{F}$ atau uji secara simultan, nilai F sebesar 24.15331 dengan tingkat Probabilitas 0,0000, lebih kecil dari 0,05. Maka variabel faktor-faktor yang mempengaruhi NPF secara simultan berpengaruh positif. Pada uji $R$ squared atau Koefisien Determinasi adalah sebesar 0.694993 atau Sama dengan 69, 50\%. Sehingga dapat dikatakan variabel CAR, FDR, Inflasi, SBIS dan BOPO mempengaruhi F sebesar $69,50 \%$ sedangkan 30,50\% dipengaruhi oleh variabel lain yang tidak diteliti.

Bank merupakan suatu lembaga intermediasi yaitu melakukan penyaluran Dana dan penghimpunan Dana, dengan dihadapkan situasi lingkungan eksternal maupun internal yang mengalami perkembangan yang pesat. Selain itu Bank syariah Akan sering berhadapan dengan berbagai jenis resiko dengan tingkat kompleksitas yang beragam dan melekat pada kegiatan usaha. Resiko Akan dihadapi oleh semua lembaga tidak terkecuali perbankan, dan resiko tersebut tidak dapat dihindari, namun kemungkinan resiko dapat diperkirakan maupun yang tidak dapat diperkirakan yang menyebabkan berdampak negatif pada pemodalan bank. Resiko tersebut tidak dapat dihindari, namun dapat dikelola atau dianalisis. Salah satu resiko dalam perbankan yaitu terjadinya kredit macet atau nonperforming financing (Karim, 2010)

Kredit ialah pemberian Dana oleh kreditur yang diberikan oleh debitur dengan asas percaya. Dengan maksud untuk memberikan kepercayaan kepada pihak debitur, sedangkan pihak debitur yang diberi pihak kepercayaan oleh debitur berkewajiban untuk menjaga kepercayaan tersebut. Yaitu dengan Cara pihak debitur membayar kredit tersebut sesuai dengan waktu yang telah disepakati bersama. Pihak kreditur disini ialah perusahaan perbankan sedangkan pihak debitur nya yaitu masyarakat, perusahaan yang membutuhkan Dana. Selain asas kepercayaan pihak bank juga berwajib untuk menganalisis kredit yang Akan diberikan kepada pihak nasabah untuk mengetahui berhak atau layak tidak layakn ya nasabah mendapatkan pinjaman (Kasmir, 2010). Hal yang perlu dilakukan oleh pihak bank yaitu menganalisa latar belakang nasabah atau perusahaan, analisis prospek usaha, dan perhitungan jaminan yang diberikan. Analisis ini dilakukan agar pihak kreditur atau bank merasa aman dan terhindar dari kredit macet. Kredit merupakan aset beresiko yang dimiliki oleh Bank, oleh karena itu Bank harus mengetahui penyebab dari kredit kemacetan, sehingga memungkinkan untuk menghindari kerugian yang dapat dialami (Maidalena, 2014)

Pemberian kredit tanpa dianalisis terlebih dahulu dapat menyebabkan membahayakan bagi perbankan. Dalam hal ini nasabah dapat memberikan data-data yang 
fiktif, sehingga memungkinkan kredit tidak layak untuk diberikan kepada nasabah. Selain itu ketika perbankan salah dalam menganalisis data nasabah Akan berakibat pada penagihan yang sulit atau kredit macet. Meskipun analisis data nasabah dibutuhkan oleh pihak bank, hal itu tidak menjadi dalam hal utama dalam menghindari resiko kredit macet yang Akan dihadapi di masa datang. Namun ada beberapa faktor lain yang memang resiko tersebut tidak dapat dihindari, seperti misalnya terjadi bencana alam, atau terjadi kebangkrutan pada usaha yang telah dibiayai yang diakibatkan oleh kesalahan dalam mengelolanya (Kasmir, 2010)

Pada bank syariah istilah non-performing financing ialah kredit macet yang diakibatkan oleh tidak mampu nya nasabah membayar pinjaman pada waktu yang telah ditentukan. Adapun Bank Indonesia telah menetapkan besarnya NPF yang baik pada perbankan ialah dibawah 5\%. Jika NPF pada perbankan syariah lebih besar dari 5\% maka hal tersebut dapat mengakibatkan profitabilitas perbankan menjadi buruk. Selain dari pada itu perbankan tidak dapat melakukan pembiayaan pada aktiva produktif lainnya.

Adapun fokus dalam penelitian ini adalah mengetahui faktor-faktor yang mempengaruhi non-performing financing, dimana variabel yang digunakan yaitu CAR, FDR, Inflasi, SBIS dan BOPO.

Capital Adequacy Ratio (CAR). CAR merupakan rasio yang mengukur seberapa jauh aktiva bank yang mengandung resiko dalam pembiayaan Dana modal dari bank itu sendiri, yakni di luar sumber-sumber Dana yang lain, seperti Dana masyarakat, pinjaman (hutang), dan lain-lain. Rasio tersebut dapat dirumuskan sebagai berikut;

$$
\text { CAR }=\frac{\text { Modal Sendiri }}{\text { ATMR }} \times 100 \%
$$

Ketentuan dari Bank Indonesia juga mengatur cara perhitungan aktiva tertimbang menurut resiko, yang terdiri atas jumlah antara Aktiva Tertimbang Menurut Resiko (ATMR) yang dihitung berdarkan nilai masing-masing pos aktiva pada neraca bank dikalikan dengan bobot resikonya masing-masing dan ATMR yang dihitung berdarkan nilai masing-masing pos aktiva pada rekening administratif bank dikalikan dengan bobot resikonya masing-masing (Dendawijaya, 2003)

Pengaruh CAR terhadap NPF. Variabel CAR pada tabel uji t menunjukkan bahwa angka sebesar 0,01 , hal ini berarti bahwa uji t tersebut mempunyai nilai yang tidak signifikan terhadap NPF, karena angka lebih besar dari 0,05. Sehingga H1 diterima dan hasil uji t yaitu CAR berpengaruh negatif dan tidak signifikan terhadap NPF. Tampaknya kecukupan modal dalam jangka panjang merupakan sorotan yang sangat penting baik dari segi makro atau mikro dalam perbankan syariah. Hasil ini didukung oleh penelitian sebelumnya yaitu oleh (Sukmana, 2015) menunjukkan hasil CAR berpengaruh negative dan signifikan terhadap NPF.

Financing to Deposit Ratio (FDR). FDR yaitu digunakan sebagai patokan untuk mengukur seberapa jauh keahlian bank dalam membayar kembali penarikan dana yang dilakukan oleh deposan dengan mengendalikan kredit yang diberikan. Dalam hal ini jika 
bank menyalurkan seluruh dana untuk pembiayaan, maka perbankan akan mendapati resiko apabila sewaktu-waktu nasabah (pemilik dana) menarik dananya, maka bank tidak mempunyai dana simpanan.

Pengaruh FDR terhadap NPF. Variabel FDR pada tabel uji t menunjukkan angka sebesar 0,005. Angka tersebut dikatakan lebih kecil dari angka signifikansi yaitu sebesar 0, 05. Sehingga dapat dikatakan bahwa FDR mempunyai pengaruh yang negatif dan signifikan terhadap NPF. Penelitian ini bertentangan dengan penelitian yang dilakukan oleh (Asnaini, 2014) bahwa FDR menunjukkan hubungan tidak berpengaruh secara signifikan terhadap NPF. Dengan alasan tingginya kemampuan pembiayaan dalam perbankan (FDR), bank Akan mampu membiayai pendanaan dalam skala besar karena Dana FDR diperoleh dari pihak ketiga yang telah dikumpulkan oleh bank (Asnaini, 2014)

Inflasi. Inflasi ialah meningkatnya harga-harga dari sebelumnya, harga yang dimaksud adalah tingkat uang yang diperlukan untuk memperoleh barang dan jasa. Secara umum inflasi berpengaruh dalam kegiatan baik secara makro atau mikro, termasuk juga mempengaruhi lajunya investasi (Wahiddudin, 2018). Selain itu akibat dari inflasi adalah terjadinya penurunan daya beli masyarakat, sehingga berdampak pada penurunan penjualan. Penurunan tersebut dapat mengakibatkan menurunnya penjualan dan return pada perusahaan. Penurunan yang terjadi Akan berakibat pada perusahaan yang Akan gagal Bayar angsuran pembiayaan. Apabila pembayaran pinjaman tersebut tidak dilakukan secara tepat waktu maka dapat berakibat pada pembiayaan kredit macet pada perbankan, yang dapat meningkatkan persentase NPF dalam perbankan semakin tinggi.

Pengaruh Inflasi terhadap NPF. Pengaruh Inflasi terhadap non-performing financing, variabel inflasi mempunyai angka signifikansi sebesar 0, 42 karena nilai signifikansi lebih besar dari 0, 05 dan nilai uji t negatif. Dengan demikian H3 diterima. Sehingga dapat dikatakan bahwa inflasi berpengaruh negative dan tidak signifikan terhadap NPF. Seiring berjalannya waktu, harga-harga bahan Baku Akan mengalami kenaikan serta Akan diikuti oleh meningkatnya kebutuhan masyarakat, tapi hal itu di luar kenaikan pendapatan. Tentunya ini Akan membawa masyarakat untuk melakukan pembiayaan di perbankan yang disebabkan oleh inflasi. Hasil uji data pengaruh inflasi terhadap NPF ini didukung oleh penelitian (Nasih, 2013) yang mengatakan bahwa inflasi berpengaruh negative signifikan terhadap NPF. Dan juga penelitian dari (Dimitrios et al., 2016) yang menjelaskan bahwa inflasi berpengaruh negative signifikan terhadap NPF.

SBIS. Dana dalam perbankan juga di salurkan pada SBIS, Dana yang disalurkan pada SBIS tersebut membuat jumlah uang yang beredar semakin berkurang dan penyaluran untuk pendanaan pembiayaan juga berkurang. Berkurangnya penyaluran pendanaan tersebut berdampak positif terhadap perbankan, karena perbankan tidak mempunyai beban dalam menanggung resiko yang lebih tinggi akibat dari berkurangnya nasabah yang di biayai (Auliani dan Syaichu, 2016)

Pengaruh SBIS terhadap NPF. Pengaruh SBIS terhadap NPF, variabel SBIS mempunyai angka signifikansi sebesar 0, 25 karena signifikansi lebih kecil dari 0, 05 dan nilai uji t negatif. Dengan demikian H4 ditolak. Maka SBIS memiliki pengaruh negatif dan tidak 
signifikan terhadap NPF. Artinya jika SBIS meningkat maka terjadi penurunan resiko pembiayaan bermasalah. Sebaliknya jika tingkat pembiayaan meningkat maka resiko yang dihadapi juga Akan meningkat. Hasil uji data ini didukung oleh penelitian sebelumnya oleh (Damanhur et al., 2018) yang menjelaskan bahwa semakin tinggi tingkat pembiayaan yang dikeluarkan, maka semakin banyak potensi kredit bermasalah. Hal ini Akan berdampak pada penurunan tingkat profitabilitas perbankan. Dalam penelitian tersebut juga memperoleh hasil SBIS tidak berpengaruh pada NPF.

BOPO. BOPO merupakan rasio biaya operasional dalam dua belas bulan terakhir terhadap pendapatan operasional dalam periode yang sama. Bank Indonesia akan memberikan nilai 100 dalam penilaian kesehatan bank umum ketika perbankan mencapai BOPO dalam angka $80 \%$. Perbedaan nilai BOPO dari angka 100 menunjukkan bahwa besar kecilnya margin pendapatan operasional terhadap biaya operasional ROA dan BOPO dapat dihitung melalui daftar laba rugi perbankan (Hasibuan, 2009).

Pengaruh BOPO terhadap NPF. Pengaruh BOPO terhadap NPF, variabel BOPO mempunyai angka signifikansi 0, 32. Maka dalam hal ini H5 di tolak karena angka lebih besar dari angka signifikan yaitu 0, 05. Dapat dikatakan bahwa BOPO memiliki pengaruh yang positif dan tidak signifikan terhadap NPF. Ini menunjukkan bahwa BOPO mempunyai pengaruh pada tingginya NPF pada bank syariah. Pendapatan bank syariah yang tinggi dengan biaya operasional yang rendah dapat menekan rasio BOPO sehingga bank syariah berada pada posisi sehat, yang artinya kecenderungan pembiayaan bermasalah Akan rendah. Hasil penelitian ini sejalan dengan (Auliani \& Syaichu, 2016) yang uji hasil datanya adalah BOPO memiliki pengaruh positif signifikan terhadap NPF.

\section{KESIMPULAN}

Paparan diatas dapat disimpulkan bahwa kredit merupakan asset yang dimiliki oleh bank syariah. Oleh karena itu bank harus menjaga seminimal mungkin untuk terjadinya pembiayaan bermasalah yang berakibat pada kerugian perbankan. Adapun hasil dari penelitian ini sebagai berikut; (1) CAR mempunyai angka signifikansi sebesar 0,001 karena nilai signifikansi lebih kecil dari 0, 05 dan nilai uji t negative. Dengan demikian H1 diterima. Sehingga dapat dikatakan bahwa CAR berpengaruh negative dan signifikan terhadap NPF. (2) Variabel FDR mempunyai angka signifikansi sebesar 0,005 karena nilai signifikan lebih kecil dari 0,05 dan nilai uji t negative. Dengan demikian H2 diterima. (3) Sehingga dapat dikatakan bahwa FDR memiliki pengaruh negative dan signifikan terhadap NPF. (4) Variable inflasi mempunyai angka signifikansi sebesar 0,42 karena nilai signifikansi lebih besar dari 0,05 dan nilai uji t negatif. Dengan demikian H3 diterima. Sehingga dapat dikatakan bahwa inflasi berpengaruh negative dan tidak signifikan terhadap NPF. (5) SBIS mempunyai angka signifikansi sebesar 0,25 karena signifikansi lebih kecil dari 0,05 dan nilai uji t negatif. Dengan demikian H4 ditolak. Maka SBIS memiliki pengaruh negatif dan tidak signifikan terhadap NPF. (6) Variabel BOPO mempunyai angka signifikansi lebih kecil 0,32 karena nilai signifikansi lebih besar dari 0,05 dan nilai uji t positif. Maka H0 diterima dan H5 ditolak. Sehingga BOPO memiliki pengaruh yang positif dan signifikan terhadap NPF. 
Penelitian ini dapat dikembangkan lagi yaitu dengan menganalisis faktor NonPerforming Financing dengan data-data terbaru serta dapat menambahkan variabel yang belum digunakan oleh penelitian sebelumnya.

\section{DAFTAR PUSTAKA}

Asnaini, S. W. (2014). Faktor-Faktor Yang Mempengaruhi Non Performing Financing (Npf) Pada Bank Umum Syariah Di Indonesia. Jurnal TEKUN, V(02), 264-280.

Auliani, M. M., dan Syaichu. (2016). Analisis Pengaruh Faktor Internal dan Faktor Eksternal Terhadap Tingkat Pembiayaan Bermasalah pada Bank Umum Syariah Di Indonesia Periode Tahun 2010-2014. Diponegoro Journal of Management, 5(3), 114. Retrieved from http://ejournal-s1.undip.ac.id/index.php/dbr.

Beck, R., and Jakubik, P. (2013). Non-Performing LoanS What MatterS in Addition to the Economic Cycle? Open Economies Review, Vol. 26 No (1515).

Ben Saada, M. (2018). The Impact Of Control Quality On The Non-Performing Loans Of Tunisian Listed Banks. Managerial Auditing Journal, 33(1), 2-15. https://doi.org/10.1108/MAJ-01-2017-1506.

Dahlan, R. (2015). Pengaruh Tingkat Bonus Sertifikat Bank Indonesia Syariah Dan Tingkat Inflasi Terhadap Pembiayaan Bank Syariah Di Indonesia. Etikonomi, 13(2), 104-117. https://doi.org/10.15408/etk.v13i2.1881.

Damanhur, Albra, W., Syamni, G., and Habibie, M. (2018). What is the Determinant of Non-Performing Financing in Branch Sharia Regional Bank in Indonesia. 265-271. https://doi.org/10.1108/978-1-78756-793-1-00081.

Dendawijaya, L. (2003). Manajemen Perbankan. Jakarta: Ghalia Indonesia.

Dimitrios, A., Helen, L., and Mike, T. (2016). Determinants of Non-Performing Loans: Evidence from Euro-Area Countries. Finance Research Letters, 18, 116-119. https://doi.org/10.1016/j.frl.2016.04.008.

Ghosh, A. (2017). Sector-Specific Analysis of Non-Performing Loans in the US Banking System and Their Macroeconomic Impact. Journal of Economics and Business, 93, 29-45. https://doi.org/10.1016/j.jeconbus.2017.06.002.

Hasibuan, M. (2009). Dasar-Dasar Perbankan. Jakarta: Bumi Aksara.

Husaeni, U. A. (2016). The Variables Effects of Murābahah in Islamic Commercial Banks. $1-16$.

Karim, A. (2010). Bank Islam Analisis Fiqih Dan Keuangan (PT Rajagra). Jakarta.

Kasmir. (2010). Dasar-Dasar Perbankan. Jakarta: PT. RajaGrafindo Persada.

Kumar, R. R. (2015). Article Information: Determinants of non-Performing Loans in Small Developing Economies: a case of Fiji's Banking Sector. Accounting Research Journal, 31(2), 192-213. https://doi.org/10.1002/pds.

Maidalena. (2014). Analisis Faktor Non Performing Financing ( NPF ) pada Industri Perbankan Syariah. Jurnal Ekonomi Dan Bisnis Islam, 1(1), 127-138. Retrieved from

http://download.portalgaruda.org/article.php?article=437905\&val=9285\&title=Anali sis Faktor Non Performing Financing (NPF) pada Industri Perbankan Syariah.

Nasih, M. (2013). The Analysis of Non Performing Financing Determinants on Indonesian Islamic Banking. Ekonomika-Bisnis, 4, 171-182.

Nur Kholis dan Lintang Kurniawati. (2018). Pengaruh Pembiayaan Bagi Hasil, Non 
Performing Financing (NPF) dan Biaya Operasional Pendapatan Operasional (BOPO) terhadap Return On Assets (ROA) pada bank umum syariah. Jurnal Ekonomi Dan Keuangan Islam, 4(2), 105-117. https://doi.org/10.20885/jeki.vol4.iss2.art3.

Ozili, P. K. (2017). Non-Performing Loans and Financial Development: New Evidence. SSRN Electronic Journal, (March), 1-35. https://doi.org/10.2139/ssrn.2892911.

Rafsanjani, H. (2018). Jurnal Masharif Al-Syariah. Jurnal Masharif Al-Syariah, Volume $3,(1)$.

Setyawati, I., Suroso, S., Suryanto, T., and Nurjannah, D. S. (2017). Does financial Performance Of Islamic Banking Is Better? Panel Data Estimation. European Research Studies Journal, 20(2), 592-606. https://doi.org/10.35808/ersj/661.

Sukmana, R. (2015). Determinants of Non Performing Financing in Indonesian Islamic Banks. Islamic Research and Training Institute, 3(13), 453. https://doi.org/10.18502/kss.v3i13.4223.

Umar, M., and Sun, G. (2016). Non-Performing Loans (NPLs), liquidity Creation, and Moral Hazard: Case of Chinese Banks. China Finance and Economic Review, 4(1). https://doi.org/10.1186/s40589-016-0034-y.

Vanni, K. M., dan Rokhman, W. (2018). Analisis Faktor-Faktor Yang Mempengaruhi Non Performing Financing Pada Perbankan Syariah Di Indonesia Tahun 2011-2016. Equilibrium: Jurnal Ekonomi Syariah, 5(2), 306. https://doi.org/10.21043/equilibrium.v5i2.2776.

Wahiddudin, M. (2018). Pengaruh Inflasi, Non Performing Financing (NPF) dan BI Rate Terhadap Pembiayaan Usaha Mikro Kecil Dan Menengah (UMKM) Pada Bank Umum Syariah 2012-2017. Al-Amwal : Jurnal Ekonomi Dan Perbankan Syari'ah, 1(1), 76-89.

Wahyuni Pratiwi, L., dan Wiagustini, N. (2016). Pengaruh Car, Bopo, Npl Dan Ldr Terhadap Profitabilitas. E-Jurnal Manajemen Universitas Udayana, 5(4), 21372166.

Wibowo, H. dan D. (2015). Pengaruh Internal Bank dan Makro Ekonomi Terhadap Non Performing Financing Perbankan Syariah di Indonesia: Periode 2010-2014. Nisbah, 1(2), 74-87.

Www.bi.go.id. (n.d.). Bank Indonesia.

www.ojk.go.id. (n.d.). OJK.

Zainul, A. A. (2006). Dasar-dasar Manajemen Bank Syariah. Jakarta: Alvabet. 